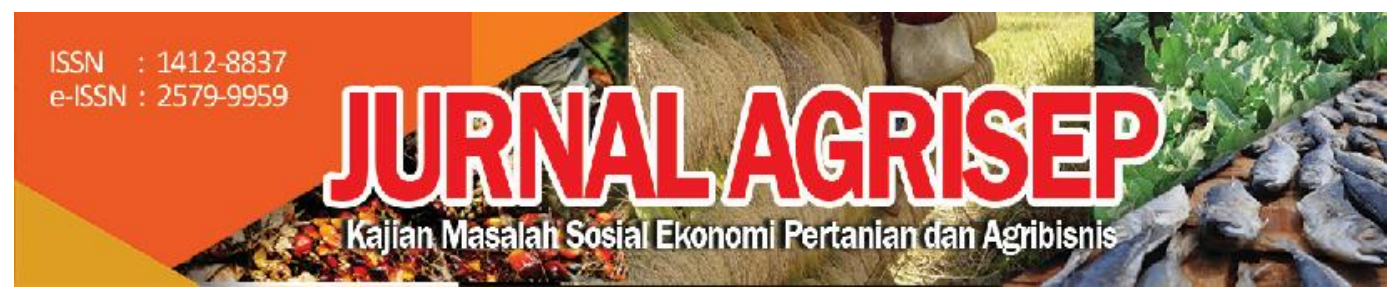

DOI: 10.31186/jagrisep.18.2.235-248

\title{
PERAN BALAI PENYULUHAN PERTANIAN (BPP) DALAM PENYULUHAN KOMODITI PANGAN (STUDI KASUS DI KABUPATEN TANAH DATAR)
}

\section{Role Of Agricultural Extension Center (BPP) in Extention of Food Commodities (Case Study In Tanah Datar District)}

\author{
Sri Wahyuni 区; Helmi; Heri Bachrizal Tanjung; Yenny Oktavia. \\ Jurusan Sosial Ekonomi Pertanian Fakultas pertanian Universitas Andalas \\ Email: sriwahyuni@agr.unand.ac.id
}

\begin{abstract}
The process of achieving food security in Indonesia is inseparable from the role of extension as the educative technical personnel and empowerment of farmers. The extention is incorporated and authorized into the agricultural scope organization unit to carry out extension activities, one of which is the AEC. The research aims to look at the role of the AEC in extention food commodities. This type of research was descriptive which was designed qualitatively using the focus group discussion (FGD) method which aimed to explored specific problems related to the role of the AEC in Tanah Datar District. The results showed that the AEC in Tanah Datar District had carried out its role in conducting food commodity counseling well, but it was still not optimal due to limited facilities and infrastructure, accommodation and financing, and lack of resources and extension staff. In addition, the role of extensions has only reached the aspect of providing inputs, cultivation and harvesting. Extensions had not fully helped independent farmers in marketing matters. Therefore, it is important to increase the role of extension agents so that they can carry out their functions properly in conducting food commodity counseling.
\end{abstract}

Keyword: BPP, extension agent, food, role. 


\begin{abstract}
ABSTRAK
Proses untuk mencapai ketahanan pangan di Indonesia tidak terlepas dari peran penyuluh sebagi tenaga teknis edukatif dan pemberdayaan petani. Penyuluh tersebut tergabung dan berwenang ke dalam satuan organisasi lingkup pertanian untuk melakukan kegiatan penyuluhan, salah satunya adalah BPP. Oleh karena itu, penelitian bertujuan untuk melihat peran BPP dalam penyuluhan komoditi pangan. Jenis penelitian ini adalah deskriptif yang didesain secara kualitatif menggunakan metode focus group discussion (FGD) yang bertujuan untuk mengeksplorasi masalah yang spesifik berkaitan dengan peran BPP di Kabupaten Tanah Datar. Hasil penelitian menunjukkan bahwa BPP di Kabupaten Tanah Datar telah melaksanakan perannya dalam melakukan penyuluhan komoditi pangan dengan baik, akan tetapi masih belum optimal disebabkan oleh keterbatasan sarana dan prasarana, akomodasi dan pembiayaan, serta kekurangan sumberdaya dan tenaga penyuluh. Selain itu, peran penyuluh baru mencapai aspek penyediaan saprodi, budidaya, dan panen. Penyuluh belum sepenuhnya membantu petani mandiri dalam hal pemasaran. Oleh karena itu, penting untuk meningkatkan peran penyuluh sehingga dapat menjalankan fungsinya dengan baik dalam melakukan penyuluhan komoditi pangan.
\end{abstract}

Kata-kata Kunci: BPP, pangan, penyuluh, peran.

\title{
PENDAHULUAN
}

Pertumbuhan penduduk semakin meningkatkan kebutuhan pangan nasional. Upaya pemerintah untuk mewujudkan swasembada dalam rangka mencapai ketahanan pangan terus dilakukan. Tahun 2015, pemerintah menargetkan pencapaian swasembada dapat dicapai dalam tiga tahun kedepan dengan pertumbuhan 2,21\% per tahun (Balitbangtan, 2015). Padi sebagai salah satu komoditi pangan utama juga terus didorong peningkatan produksinya, yang dilakukan melalui berbagai cara seperti Gerakan Penerapan Pengelolaan Tanaman Terpadu (GP-PTT) dan berbagai Upaya Khusus (Upsus) (Dirjen Tanaman Pangan Kementan, 2017).

Keseluruhan proses untuk mencapai ketahanan pangan tersebut tidak terlepas dari peran penyuluh sebagi tenaga teknis edukatif dan pemberdayaan petani. Undang-Undang No. 16 Tahun 2006 menyebutkan bahwa penyuluhan adalah proses pembelajaran bagi pelaku utama serta pelaku usaha agar mereka mau dan mampu menolong dan mengorganisasikan dirinya dalam mengakses informasi pasar, teknologi, permodalan, dan sumberdaya lainnya, sebagai upaya untuk meningkatkan produktivitas, efisiensi usaha, pendapatan, dan kesejahteraannya, serta meningkatkan kesadaran dalam pelestarian fungsi lingkungan hidup. Berdasarkan Peraturan Menteri Pertanian No. 16 Tahun 2008, penyuluh tersebut tergabung dan berwenang ke dalam organisasi pada satuan organisasi lingkup pertanian untuk 
melakukan kegiatan penyuluhan. Salah satu organisasi tersebut adalah Balai Penyuluhan Pertanian.

Balai Penyuluhan Pertanian (BPP) merupakan basis pelaksanaan penyuluhan pertanian di unit terkecil, yakni kecamatan. Berdasarkan Database Ketenagaan Penyuluhan Pertanian (Simluhtan, 2018), hingga tahun 2018 ketenagaan penyuluhan berasal dari penyuluh PNS sebanyak 25.247 orang, penyuluh THLTBPP sebanyak 16.070 orang, penyuluh swasta sebanyak 103 orang dan penyuluh swadaya sebanyak 25.402 orang. Lebih lanjut, data tersebut juga disebutkan bahwa pada 6.998 kecamatan yang ada di Indonesia, hanya terdapat 5.643 unit BPP. Masih terdapat BPP yang membina lebih dari satu kecamatan, yakni 1.355 BPP. Hal ini mengindikasikan bahwa terdapat ketimpangan jumlah BPP dengan kecamatan binaan, dimana kebutuhan penyuluh masih tinggi guna memenuhi 1.355 BPP tersebut.

Provinsi Sumatera Barat sebagai salah satu sentra produksi tanaman pangan di pulau Sumatera juga tidak terlepas dari permasalahan tersebut. Berdasarkan BPPSDMP (2017), Sumatera Barat yang memiliki 179 kecamatan dan 1.140 desa, tersebar penyuluh PNS sebanyak 728 orang, THL TBPP 625 orang, Penyuluh Swadaya 660 orang dan 1 orang Penyuluh Swasta (Kelembagaan Penyuluhan Petanian, 2017). Padahal, Sumatera Barat memiliki potensi pengembangan pangan terutama komoditas pangan yang menjanjikan dengan beragam teknis budidaya yang sudah diakui tidak hanya di skala nasional, juga hingga internasional. Salah satu bentuk teknis budidaya padi yang telah diakui tersebut berasal dari kearifan lokal masyarakat setempat, yaitu teknologi budidaya padi salibu di Kabupaten Tanah Datar.

Kabupaten Tanah Datar merupakan salah satu sentra pengembangan budidaya padi salibu sebagai komoditas pangan di Sumatera Barat. Meskipun padi salibu mepakan salah satu bentuk kearifan lokal masyarakat Kabupaten Tanah Datar, akan tetapi masih terdapat petani yang belum mengetahui tata cara budidayanya dan lebih banyak lagi petani yang belum menerapkannya. Untuk menyebarluaskan teknologi tersebut agar diadopsi oleh petani, diperlukan peran penyuluh pertanian. Berdasarkan data Simluhtan per Oktober 2018 (Simluhtan, 2018), Kabupaten Tanah Datar memiliki 14 kecamatan dan 75 desa, yang mana tersebar penyuluh PNS sebanyak 48 orang, THL-TBPP 40 orang, dan Penyuluh Swadaya 48 orang. Keseluruhan penyuluh tersebut tersebar pada unit-unit BPP yang mewakili 14 kecamatan dan 75 desa di Kabupaten Tanah Datar. Observasi di lapangan menunjukkan bahwa 1 orang penyuluh di Kabupaten Tanah Datar dapat membina lebih dari 1 desa. Hal ini jelas memperlihatkan ketimpangan serupa yang dialami Indonesia secara keseluruhan.

Demi mencapai swasembada untuk ketahanan pangan, sangat jelas diperlukan optimalisasi peran penyuluh pertanian sebagai agen pembaruan (agent of change) pembangunan pertanian. Penguatan peran BPP sebagai wadah bagi penyuluh pertanian perlu dilakukan. Penguatan fungsi tersebut perlu dilakukan di seluruh 
aspek, baik di tingkat BPP itu sendiri hingga ke tingkat petani dalam hal budidaya, pengelolaan pasca panen, hingga pemasaran. Oleh karena itu, perlu melakukan penelitian mengenai peran BPP dalam penyuluhan komoditi pangan.

\section{METODE PENELITIAN}

Penelitian ini dilaksanakan pada bulan Agustus-Oktober 2018. Jenis penelitian ini adalah penelitian deskriptif yang didesain secara kualitatif untuk mendapatkan gambaran dan informasi yang lebih mendalam untuk melihat peran Badan Penyuluhan Pertanian (BPP) di Kabupaten Tanah Datar. Penelitian deskripsi utamanya ditujukan untuk menjelaskan suatu phenomena atau karakteristik suatu phenomena (Sukiyono, 2018). Proses penelitian deskriptif berupa pengumpulan dan penyusunan data, serta analisis dan penafsiran data tersebut. Metode yang digunakan dalam penelitian ini adalah metode focus group discussion (FGD) yang bertujuan untuk mengeksplorasi masalah yang spesifik berkaitan dengan peran BPP di Kabupaten Tanah Datar, sehingga dapat ditarik kesimpulan terhadap makna-makna intersubjektif yang mungkin sulit dimaknai sendiri oleh peneliti karena dihalangi oleh dorongan subjektivitas peneliti (Kresno et al., 1999). Sumber data dalam penelitian ini dipilih secara purposive (sengaja) yang terdiri atas 2 orang penyuluh tingkat kabupaten yang mewakili penyuluh di Kabupaten Tanah Datar; 6 orang penyuluh di kecamatan terpilih yaitu 2 orang penyuluh Kecamatan Sungai Tarab, 2 orang penyuluh dari Kecamatan Lima Kaum, dan 2 orang penyuluh dari Kecamatan Batipuh; dan 8 orang ketua kelompok tani terpilih yang mewakili kelompok tani yang terdapat di Kabupaten Tanah datar. Teknik pengumpulan data dalam penelitian ini dilakukan dengan cara wawancara langsung secara mendalam, observasi, dan studi dokumentasi; sehingga jenis data dalam penelitian ini terdiri atas data primer yang didapatkan dari FGD dan wawancara dengan sumber data, dan data sekunder yang didapatkan dari dokumen yang menunjang tujuan penelitian.

\section{HASIL DAN PEMBAHASAN}

\section{Profil Kabupaten Tanah Datar}

Kabupaten Tanah Datar merupakan salah satu kabupaten yang berada dalam Provinsi Sumatera Barat dengan luas $133.600 \mathrm{Ha}\left(1.336 \mathrm{~km}^{2}\right)$, berada pada $0^{\circ} 27^{\prime} 12^{\prime \prime} \mathrm{LU} 100^{\circ} 35^{\prime} 38^{\prime \prime}$ BT. Kabupaten Tanah Datar memiliki 14 kecamatan, 75 nagari, dan 395 jorong. Kabupaten Tanah Datar merupakan Tujuh Kabupaten Terbaik di Indonesia dari 400 kabupaten yang ada. Penghargaan ini diberikan pada tahun 2003 oleh Lembaga International Partnership dan Kedutaan Inggris. Lembaga Ilmu Pengetahuan Indonesia (LIPI) menobatkan Kabupaten Tanah 
Datar sebagai satu dari empat daerah paling berprestasi dan berhasil melaksanakan otonomi daerah.

Kabupaten Tanah Datar terletak di antara dua gunung, yaitu Gunung Merapi dan Gunung Singgalang. Kondisi topografi ini didominasi oleh daerah perbukitan, serta memiliki dua pertiga bagian danau Singkarak. Kondisi topografis Kabupaten Tanah Datar adalah sebagai berikut:

1. Wilayah Datar 0-3\% dengan luas 6.189 Ha atau 6.63\% dari luar wilayah Kabupaten Tanah Datar

2. Wilayah Berombak 3-8\% dengan luas $3.594 \mathrm{Ha}$ atau 2,67\% dari luar wilayah Kabupaten Tanah Datar

3. Wilayah Bergelombang $8-15 \%$ dengan luas $43.922 \mathrm{Ha}$ atau $32.93 \%$ dari luas Kabupaten Tanah Datar

4. Kemiringan di atas $15 \%$ dengan luas wilayah $79.895 \mathrm{Ha}$ atau $59.77 \%$ dari luas Kabupaten Tanah Datar

Secara umum iklim di kawasan Kabupaten Tanah Datar adalah sedang dengan temperatur antara $12{ }^{\circ} \mathrm{C}-25{ }^{\circ} \mathrm{C}$ dengan curah hujan rata-rata lebih dari $3.000 \mathrm{~mm}$ per tahun. Hujan kebanyakan turun pada bulan September hingga bulan Februari. Curah hujan yang cukup tinggi ini menyebabkan ketersediaan air cukup, sehingga memungkinkan usaha pertanian secara luas dapat dikembangkan.

\section{Profil BBP Kabupaten Tanah Datar}

Pemerintah melakukan berbagai upaya dalam rangka mencapai visi ketahanan pangan, salah satunya meningkatkan produktivitas dalam sektor-sektor pertanian di berbagai daerah seluruh Indonesia (Kementan, 2015). Keseluruhan proses untuk mencapai ketahanan pangan tersebut tidak terlepas dari peran penyuluh sebagi tenaga teknis edukatif dan pemberdayaan petani melalui kegiatan penyuluhan. Undang-Undang No. 16 Tahun 2006 menyebutkan bahwa penyuluhan adalah proses pembelajaran bagi pelaku utama serta pelaku usaha agar mereka mau dan mampu menolong dan mengorganisasikan dirinya dalam mengakses informasi pasar, teknologi, permodalan, dan sumberdaya lainnya, sebagai upaya untuk meningkatkan produktivitas, efisiensi usaha, pendapatan, dan kesejahteraannya, serta meningkatkan kesadaran dalam pelestarian fungsi lingkungan hidup. Berdasarkan Peraturan Menteri Pertanian No. 61 Tahun 2008, penyuluh tersebut tergabung dan berwenang ke dalam organisasi pada satuan organisasi lingkup pertanian untuk melakukan kegiatan penyuluhan. Salah satu organisasi tersebut adalah Balai Penyuluhan Pertanian.

Provinsi Sumatera Barat memiliki potensi pengembangan komoditas pangan terutama padi yang menjanjikan. Hal ini terbukti bahwa pada tahun 2016, sektor pertanian menjadi penyumbang terbesar dalam Produk Domestik Regional Bruto (PDRB) Sumatera Barat yang mencapai 23,10 persen. Salah satu daerah yang menjadikan pertanian sebagai sektor utama di Sumatera Barat adalah Kabupaten Tanah Datar. Sebagai daerah agraris, lebih $70 \%$ penduduk di 
Kabupaten Tanag Datar bekerja pada sektor pertanian, baik pertanian tanaman pangan, perkebunan, perikanan, maupun peternakan. Sebagai daerah dengan potensi pertanian yang sangat besar, aktivitas pertanian oleh petani dipantau dan dibina langsung oleh penyuluh-penyuluh yang berasal dari Balai Penyuluhan Pertanian (BPP) di Kabupaten Tanah Datar. Menurut data Sistem Informasi Manajemen Penyuluhan Pertanian (Simluhtan, 2018), jumlah BPP/BPK di Kabupaten Tanah Datar adalah 14 BPP/BPK yang mewakili 14 kecamatan di Kabupaten Tanah Datar. Uraian BPP/BPK pada masing-masing kecamatan dapat dilihat pada Tabel 1.

Tabel 1. Kelembagaan Penyuluhan Pertanian Tingkat Kecamatan Kabupaten Tanah Datar

\begin{tabular}{|c|c|c|c|c|c|c|c|}
\hline \multirow[b]{2}{*}{ No. } & \multirow[b]{2}{*}{ Nama BP3K } & \multirow[b]{2}{*}{$\begin{array}{c}\text { Nama } \\
\text { Kelembagaan }\end{array}$} & \multirow{2}{*}{$\begin{array}{l}\text { Wilayah } \\
\text { Kecamatan }\end{array}$} & \multirow[b]{2}{*}{$\begin{array}{c}\text { Nama } \\
\text { Pimpinan }\end{array}$} & \multicolumn{3}{|c|}{ Jumlah Penyuluh } \\
\hline & & & & & $\begin{array}{c}\text { Penyuluh } \\
\text { PNS }\end{array}$ & $\begin{array}{l}\text { THL- } \\
\text { TB PP }\end{array}$ & $\begin{array}{c}\text { Penyuluh } \\
\text { Swadaya }\end{array}$ \\
\hline 1. & $\begin{array}{l}\text { BPP Sungai } \\
\text { Tarab }\end{array}$ & $\begin{array}{l}\text { Balai } \\
\text { Penyuluhan } \\
\text { Pertanian }\end{array}$ & $\begin{array}{l}\text { Sungai } \\
\text { Tarab }\end{array}$ & $\begin{array}{l}\text { Yufrizal, } \\
\text { S.Pt }\end{array}$ & 7 & 3 & 4 \\
\hline 2. & $\begin{array}{l}\text { Tanjung } \\
\text { Emas }\end{array}$ & $\begin{array}{l}\text { Balai } \\
\text { Penyuluhan } \\
\text { Pertanian }\end{array}$ & $\begin{array}{l}\text { Tanjung } \\
\text { Emas }\end{array}$ & Malyunis & 4 & 1 & 4 \\
\hline 3. & $\begin{array}{l}\text { Balai } \\
\text { Penyuluhan } \\
\text { Kecamatan } \\
\text { Lima Kaum }\end{array}$ & $\begin{array}{l}\text { Balai } \\
\text { Penyuluhan } \\
\text { Kecamatan }\end{array}$ & Lima Kaum & $\begin{array}{l}\text { Rosnidel, } \\
\text { S.Pt }\end{array}$ & 5 & 1 & 5 \\
\hline 4. & $\begin{array}{l}\text { BPK } \\
\text { Batipuh }\end{array}$ & $\begin{array}{l}\text { Balai } \\
\text { Penyuluhan } \\
\text { Kecamatan }\end{array}$ & Batipuh & $\begin{array}{l}\text { Trivera, } \\
\text { S.Pt }\end{array}$ & 2 & 5 & 8 \\
\hline 5. & $\begin{array}{l}\text { BPK Lintau } \\
\text { Buo }\end{array}$ & $\begin{array}{l}\text { Balai } \\
\text { Penyuluhan } \\
\text { Kecamatan }\end{array}$ & Lintau Buo & $\begin{array}{l}\text { Syafrijal, } \\
\text { A.Md }\end{array}$ & 4 & 2 & 2 \\
\hline 6. & $\begin{array}{l}\text { BPK Lintau } \\
\text { Buo Utara }\end{array}$ & $\begin{array}{l}\text { Balai } \\
\text { Penyuluhan } \\
\text { Kecamatan }\end{array}$ & $\begin{array}{l}\text { Lintau Buo } \\
\text { Utara }\end{array}$ & Effendi & 2 & 6 & 1 \\
\hline 7. & $\begin{array}{l}\text { BPK } \\
\text { Padang } \\
\text { Ganting }\end{array}$ & $\begin{array}{l}\text { Balai } \\
\text { Penyuluhan } \\
\text { Kecamatan }\end{array}$ & $\begin{array}{l}\text { Padang } \\
\text { Ganting }\end{array}$ & $\begin{array}{l}\text { Rostina, } \\
\text { SP }\end{array}$ & 3 & 2 & 2 \\
\hline 8. & $\begin{array}{l}\text { BPK } \\
\text { Pariangan }\end{array}$ & $\begin{array}{l}\text { Balai } \\
\text { Penyuluhan } \\
\text { Kecamatan }\end{array}$ & Pariangan & $\begin{array}{l}\text { Yeni } \\
\text { Marlis, } \\
\text { S.Pt }\end{array}$ & 4 & 3 & 5 \\
\hline 9. & $\begin{array}{l}\text { BPK } \\
\text { Rambatan }\end{array}$ & $\begin{array}{l}\text { Balai } \\
\text { Penyuluhan } \\
\text { Kecamatan }\end{array}$ & Rambatan & $\begin{array}{l}\text { Tunasril, } \\
\text { A.Md }\end{array}$ & 4 & 1 & 3 \\
\hline
\end{tabular}




\begin{tabular}{|c|c|c|c|c|c|c|c|}
\hline \multirow[b]{2}{*}{ No. } & \multirow[b]{2}{*}{ Nama BP3K } & \multirow[b]{2}{*}{$\begin{array}{c}\text { Nama } \\
\text { Kelembagaan }\end{array}$} & \multirow[b]{2}{*}{$\begin{array}{c}\text { Wilayah } \\
\text { Kecamatan }\end{array}$} & \multirow[b]{2}{*}{$\begin{array}{c}\text { Nama } \\
\text { Pimpinan }\end{array}$} & \multicolumn{3}{|c|}{ Jumlah Penyuluh } \\
\hline & & & & & $\begin{array}{l}\text { Penyuluh } \\
\text { PNS }\end{array}$ & $\begin{array}{l}\text { THL- } \\
\text { TB PP }\end{array}$ & $\begin{array}{c}\text { Penyuluh } \\
\text { Swadaya }\end{array}$ \\
\hline 10. & $\begin{array}{l}\text { BPK } \\
\text { Salimpaung }\end{array}$ & $\begin{array}{l}\text { Balai } \\
\text { Penyuluhan } \\
\text { Kecamatan }\end{array}$ & Salimpaung & $\begin{array}{l}\text { Erzanedi, } \\
\text { S.Pt }\end{array}$ & 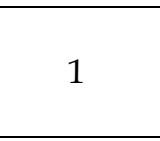 & 6 & 5 \\
\hline 11. & $\begin{array}{l}\text { BPK } \\
\text { Sungayang }\end{array}$ & $\begin{array}{l}\text { Balai } \\
\text { Penyuluhan } \\
\text { Kecamatan }\end{array}$ & Sungayang & $\begin{array}{l}\text { Nofriani. } \\
\mathrm{N}\end{array}$ & 4 & 2 & 2 \\
\hline 12. & $\begin{array}{l}\text { BPK } \\
\text { Tanjung } \\
\text { Baru }\end{array}$ & $\begin{array}{l}\text { Balai } \\
\text { Penyuluhan } \\
\text { Kecamatan }\end{array}$ & $\begin{array}{l}\text { Tanjung } \\
\text { Baru }\end{array}$ & $\begin{array}{l}\text { Marwan, } \\
\text { S.Pt }\end{array}$ & 2 & 2 & 1 \\
\hline 13. & BPK X Koto & $\begin{array}{l}\text { Balai } \\
\text { Penyuluhan } \\
\text { Kecamatan }\end{array}$ & $\begin{array}{l}\text { Sepuluh } \\
\text { Koto }\end{array}$ & $\begin{array}{l}\text { Khairil, } \\
\text { SP }\end{array}$ & 2 & 4 & 2 \\
\hline 14. & $\begin{array}{l}\text { BPP } \\
\text { Batipuh } \\
\text { Selatan }\end{array}$ & $\begin{array}{l}\text { Balai } \\
\text { Penyuluhan } \\
\text { Pertanian }\end{array}$ & $\begin{array}{l}\text { Batipuh } \\
\text { Selatan }\end{array}$ & $\begin{array}{l}\text { Virda } \\
\text { Yufanto } \\
\text { Rajab, } \\
\text { S.Pt }\end{array}$ & 3 & 2 & 3 \\
\hline
\end{tabular}

Sumber: Simluhtan (2018)

Berdasarkan data Simluhtan (2018), diketahui bahwa umumnya kondisi bangunan BPP di setiap kecamatan merupakan milik sendiri (pemerintah) dengan kondisi bangunan yang masih baik. Akan tetapi, kondisi bangunan BPP Sungai Tarab berada dalam kondisi rusak/tidak baik, dan saat ini menempati bangunan semi permanen di tengah sawah petani. Selain itu, menurut salah satu penyuluh di Kecamatan Sungayang, mereka tidak memiliki kantor tetap, bahkan sudah berpindah sebanyak tiga kali. Hal ini menunjukkan bahwa masih terdapat fasilitas dan akomodasi BPP yang kurang memadai di Kabupaten Tanah Datar.

Tabel 1 memperlihatkan bahwa tenaga penyuluh yang mendampingi petani di setiap kecamatan masih sedikit, yaitu sebanyak 1(satu) orang penyuluh untuk 3 (tiga) - 4 (empat) nagari (desa). Padahal menurut Peraturan Menteri Pertanian Nomor 01/Permentan/OT.140/1/2008, dalam rangka melakukan percepatanpembangunan pertanian yang salah satunya ditempuh melaluiRevitalisasi Penyuluhan Pertanian, idealnya hanya terdapat 1 (satu) penyuluh dalam 1 (satu) desa (nagari). Tidak idealnya jumlah tenaga penyuluh tersebut ditekankan oleh salah satu penyuluh di Kecamatan Sungai Tarab, Dona Dafila, sebagai berikut:

"Terjadi overload tanggung jawab penyuluh terhadap wilayah kerja, seperti satu orang penyuluh mengelola tiga wilayah nagari. Hal tersebut saya alami sendiri, sehingga saya sangat kewalahan. Oleh karena itu, saya kira sangat perlu penambahan jumlah penyuluh pertanian." 
Yurinis, penyuluh BPK Kecamatan X Koto, turut menegaskan hal serupa. Ia menyatakan bahwa:

"Tenaga penyuluh masih sangat kurang di wilayah kerja kami. Kami mengalami kelebihan beban kerja. Bukan hanya kekurangan penyuluh PNS dan Tenaga Harian Lepas (THL), akan tetapi juga kekurangan penyuluh swadaya. BPP dan kami penyuluh juga kurang mendapatkan fasilitas. Kami sering disuruh melakukan tugas lapagan, akan tetapi akomodasi yang diberikan tidak cukup dan belum sesuai dengan kebutuhan kegiatan penyuluhan.”

Simluhtan (2018) memperlihatkan bahwa terdapat berbagai komoditas pertanian unggulan pada masing-masing kecamatan yang juga turut didampingi oleh penyuluh. Di Kecamatan Sungai Tarab, Lima Kaum, Pariangan, X Koto, dan Batipuh misalnya, komoditas utama wilayah adalah padi dengan luas lahan lebih dari 1500 hektar. Sementara itu, Kecamatan Rambatan mengandalkan komoditas kakao sebagai sektor unggulan, dengan luas lahan 1136 hektar. Selain komoditas utama tersebut, juga terdapat komoditas lain seperti jagung, aneka kacangkacangan, aneka cabai, aneka umbi, dan karet.

\section{Peran BPP dalam Penyuluhan Komoditi Pangan}

Proses untuk mencapai ketahanan pangan tidak terlepas dari peran penyuluh sebagai tenaga teknis edukatif dan pemberdayaan petani, sebagaimana mandat dari Undang-Undang No. 16 Tahun 2006.Sebagaimana yang juga dinyatakan oleh Syahyuti (2016), diberlakukannya undang-undang tersebut sebagai perbaikan dari sistem sebelumnya diharapkan kegiatan penyuluhan bukan hanya sekedar proses alih teknologi, melainkan lebih kepada tercapainya kemandirian petani (Sadono, 2008) serta kelembagaan penyuluhan yang tertata dengan baik dan terorganisasi (Setiawan, 2005). Dengan demikian, kegiatan penyuluhan tidak lagi hanya ditekankan pada peningkatan produksi pangan untuk mencapai swasembada seperti halnya pada program REPELITA I-V pada masa Orde Baru, akan tetapi juga memperhatikan edukasi dan keberdayaan petani sehingga ketahanan pangan sebagai tujuan utama tidak lagi menjadi program sekali jalan, akan tetapi berkelanjutan atas dasar kesadaran, kemandirian, dan kemampuan petani.

Peraturan Menteri Pertanian (Permentan) No. 61 Tahun 2008 juga menyebutkan bahwa salah satu upaya pemerintah untuk mendukung program ketahanan pangan adalah dengan meningkatkan kinerja penyuluh pertanian melalui Revitalisasi Penyuluhan Pertanian untuk mencapai keberhasilan pembangunan pertanian. Hal ini diwujudkan dengan memaksimalkan fungsi 
kelembagaan penyuluhan pertanian dengan menggabungkan dan memberikan wewenang kepada penyuluh ke dalam kelembagaan pertanian untuk melakukan kegiatan penyuluhan. Pelawi et al. (2016) menjelaskan bahwa lembaga penyuluhan pertanian mempunyai peran strategis karena mempunyai tugas dan fungsi untuk menyelenggarakan pendidikan non-formal bagi petani/nelayan serta mendampingi petani, mengajarkan pengetahuan dan keterampilan tentang usahatani, mendidik petani agar mampu memberdayakan semua potensinya, menyebarkan inovasi-inovasi baru kepada petani tentang bagaimana berusaha tani dengan baik.

Salah satu kelembagaan penyuluhan pertanian tersebut adalah Balai Penyuluhan Pertanian (BPP), di mana menurut Permentan No. 61 Tahun 2008, merupakan satuan unit kerja penyuluhan pertanian di tingkat kecamatan, sehingga seringkali juga disebut sebagai Balai Penyuluhan Kecamatan (BPK). Menurut UU No. 16 Tahun 2006, BPP berfungsi sebagai tempat pertemuan para penyuluh, pelaku utama, dan pelaku usaha. Selain itu, BPP juga memiliki fungsi di antaranya untuk menyusun program penyuluhan pada tingkat kecamatan sejalan dengan program penyuluhan kabupaten/kota; melaksanakan penyuluhan berdasarkan program penyuluhan; menyediakan dan menyebarkan informasi teknologi, sarana produksi, pembiayaan, dan pasar; memfasilitasi pengembangan kelembagaan dan kemitraan pelaku utama dan pelaku usaha;dan melaksanakan proses pembelajaran melalui percontohan dan pengembangan model usaha tani bagi pelaku utama dan pelaku usaha.

Berdasarkan uraian UU No. 16 Tahun 2006 tersebut, terlihat bahwa peran BPP sangat besar sebagai lembaga dalam kegiatan penyuluhan, salah satunya komoditi pangan. BPP melalui agen penyuluhannya tidak hanya berperan dalam transfer teknologi, edukasi dan pemberdayaan petani, akan tetapi penyuluh dituntut untuk turut melakukan perencanaan program dan kegiatan yang bersinergi dengan kebutuhan petani. Oleh karena itu, perlu interaksi intensif antara penyuluh dan petani untuk memperoleh need assesment petani. Hal tersebut berlaku untuk BPP di seluruh Indonesia, termasuk BPP pada setiap kecamatan di Kabupaten Tanah Datar. Seluruh fungsi tersebut harus dilaksanakan secara bersinergi oleh BPP dalam melakukan kegiatan penyuluhan untuk tanaman pangan.

Menurut salah seorang narasumber dari kegiatan FGD, pada kenyataannya koordinator BPP belum memiliki perencanaan menyeluruh terhadap Gapoktan. Hal tersebut seperti yang diungkapkannya berikut:

"Koordinator BPP tidak memiliki planning untuk kami para petani, program untuk petani tidak ada oleh BPP, sehingga kami agak kesulitan. Selain itu, perubahan kebijakan oleh pemerintah kami rasa memberatkan dan masih belum mensejahterakan petani..." (Bustami Nurdin, Ketua Gapoktan Rambatan). 
Pernyataan tersebut memperlihatkan bahwa peran BPP di Kabupaten Tanah Datar dalam melakukan perencanaan program penyuluhan di lokasi kerja mereka belum optimal, sehingga pelaksanaan seperti yang dimaksudkan pada undangundang tersebut juga belum mencapai target. Hal tersebut dapat terjadi karena berbagai hal, seperti kurangnya sarana dan prasarana penyulu dalam melaksanakan tugas, keterbatasan jumlah penyuluh, dan kelebihan beban kerja penyuluh sehingga tidak mampu mengelola seluruh kelompok tani dan gabungan kelompok tani di setiap wilayah kerja. Hal ini seperti yang diungkapkan oleh salah satu penyuluh sebagai berikut:

"Tupoksi penyuluh khususnya di daerah kami, Kabupaten Tanah Datar, tidak bisa berjalan maksimal karena tugas admininstratif yang banyak dan padat. Pemerintah masih memandang kami para penyuluh sebagai alat, sehingga kurang memperhatikan kesejahteraan penyuluh, padahal penyuluh sangat dibutuhkan. Kami sebagai penyuluh senior tidak diberikan reward dalam menyelesaikan tugas. Rekrutmen tenaga penyuluh ini ada, tapi tidak difungsikan sebagaimana mestinya..." (Deswita, Penyuluh Kabupaten Tanah Datar).

Syahyuti (2016) menyebutkan bahwa untuk mengoptimalkan fungsi penyuluhan pada zaman sekarang melalui sistem penyuluhan modern, dibutuhkan perubahan struktur kelembagaan, yaitu lingkungan yang mampu mendorong kerja sama dan koordinasi, melalui pengembangan struktur kelembagaan salah satunya dengan cara membangun relasi formal antara lembaga pendidikan dan penelitian serta melakukan konsultasi dengan lembaga swasta. Selanjutnya, Jamil et al. (2012) menguraikan bahwa setidaknya terdapat beberapa faktor yang memengaruhi kinerja BPP dalam melaksanakan tugasnya, yaitu pengembangan BPP, keunggulan mutu BPP, sumberdaya manusia, sarana dan pembiayaan, dan rencana strategis. Akan tetapi, berdasarkan observasi di lapangan dan keterangan narasumber baik penyuluh maupun petani, hal tersebut masih belum dilaksanakan dengan maksimal seperti masih minimnya sarana dan pembiaaan, kurang terlaksananya rencana strategis dan kurangnya tenaga penyuluh sehingga tidak dapat merangkul semua kelompok tani dengan optimal.

Kelembagaan penyuluhan merupakan faktor determinan yang sangat berpengaruh terhadap peningkatan kualitas sumberdaya manusia pertanian dan tercapainya tujuan dari pembangunan pertanian (Lesmana, 2007). Hasil FGD dan observasi di lapangan menunjukkan bahwa BPP berperan dalam kegiatan penyuluhan komoditi pangan sebagai komoditi utama dan unggulan di Kabupaten Tanah Datar. Akan tetapi, peran BPP dalam melakukan penyuluhan saat ini hanya pada aspek hulu dalam penyediaan sarana produksi seperti mesin potong dan pupuk, kegiatan budidaya seperti kegiatan sekolah lapang, hingga panen. Hal 
tersebut memperlihatkan bahwa program pemerintah untuk mencapai swasembada pangan kembali mendorong petani untuk meningkatkan produktivitas pangan, akan tetapi belum memberikan solusi bagi masalah pokok lainnya, yaitu aspek pemasaran. Observasi di lapangan menunjukkan bahwa petani padi Kecamatan Sungai Tarab terikat dengan tengkulak baik di awal musim tanam untuk modal awal, maupun ketika panen untuk kegiatan pemasaran. Hal ini menyulitkan petani karena baik harga maupun metode pembayaran diatur oleh tengkulak. Tidak jarang hasil panen petani tidak dibayar tepat waktu sehingga menyulitkan petani untuk mendapatkan modal untuk musim tanam selanjutnya. Hal serupa juga ditegaskan oleh narasumber FGD dari Nagari Bukik Panjang sebagai berikut:

"Modal kami untuk menanam berasal dari tengkulak. Begitu pula hasil panen kami dipegang oleh tengkulak, sehingga kami penghasilan yang kami dapatkan tidak seberapa...” (Edward, Petani Jagung).

Sebagaimana yang dijelaskan oleh UU No. 16 tahun 2008, kegiatan penyuluhan merupakan proses pembelajaran bagi pelaku utama serta pelaku usaha agar mereka maudan mampu menolong dan mengorganisasikan dirinya dalam mengakses informasipasar, teknologi, permodalan, dan sumberdaya lainnya, sebagai upaya untukmeningkatkan produktivitas, efisiensi usaha, pendapatan, dan kesejahteraannya, sertameningkatkan kesadaran dalam pelestarian fungsi lingkungan hidup. Oleh karena itu, kegiatan penyuluhan di Kabupaten Tanah Datar harus meningkatkan perannya dalam penyuluhan komoditi pangan agar petani tidak hanya mampu dalam upaya peningkatan produktivitas pangan, akan tetapi juga dapat menolong dirinya sendiri dalam mengakses pasar untuk meningkatkan usaha dan pendapatan mereka. Penyuluhan pertanian yang diamanatkan oleh UU No. 16 tahun 2008 tidak hanya peningkatan produksi pertanian seperti paradigma penyuluhan lama, akan tetapi juga peningkatan terhadap pengetahuan dan informasi pasar, sebab pengertian pertanian menurut UU tersebut meliputi usaha hulu,usaha tani, agroindustri, pemasaran, dan jasa penunjang pengelolaan sumber dayaalam hayati dalam agroekosistem yang sesuai dan berkelanjutan.

Untuk mengoptimalkan peran BPP dalam melaksanakan penyuluhan komoditi pangan di Kabupaten Tanah Datar, perlu dilakukan pembenahan dan perbaikan dalam berbagai aspek. Aspek-aspek tersebut mencakup sarana dan prasarana, akomodasi dan pembiayaan, serta peningkatan kualitas dan kuantitas sumberdaya penyuluh.Saat ini, dukungan terhadap kegiatan penyuluhan di Kabupaten Tanah Datar masih kurang. Salah satunya terhadap hal akomodasi dan pembiayaan transportasi penyuluh. Seperti yang dinyatakan oleh salah satu penyuluh, bahwa setiap penyuluh hanya diberikan kupon BBM sebanyak 5 (lima) Liter setiap bulannya. Hal ini sangat tidak mencukupi kebutuhan penyuluh yang 
harus mengunjungi 3 (tiga) hingga 4 (empat) nagari (desa) dengan medan yang cukup berat dan jarak yang cukup jauh.

Hasil penelitian Marlianti et al. (2008) dan Jamil et al. (2012) menyebutkan bahwa kualitas kinerja penyuluh dipengaruhi oleh kompetensi penyuluh, akses terhadap sarana dan prasara, serta dukungan pemerintah. Selain itu, perlu penegasan regulasi mengenai kedudukan BPP yang harusnya berdiri secara independen tanpa terikat dengan berbagai kepentingan, seperti yang juga disebutkan oleh salah satu narasumber penyuluh dalam FGD. Hal serupa juga ditegaskan dalam hasil penelitian Syabrina et al. (2009) bahwa fungsi pelayanan dan fungsi pengaturan masih mendominasi sistim kerja penyuluhan. Ia menyebutkan bahwa keberadaan kelembagaan penyuluhan belum dapat mengakomodir kepentingan penyuluh, dan seperti halnya di Kabupaten Tanah Datar, frekuensi LAKU (latihan dan kunjungan) belum sepenuhnya terlaksana karena kekurangan sumberdaya penyuluh yang dapat mengakomodasi seluruh wilayah kerja.

\section{SIMPULAN DAN SARAN}

\section{Simpulan}

Balai Penyuluhan Pertanian (BPP) sebagai wadah penyuluh mempunyai peran penting dalam membantu petani menjadi mandirisehingga dapat mengatasi permasalahan yang dihadapinya sehingga meningkat derajat kehidupannya. BPP di Kabupaten Tanah Datar telah melaksanakan perannya dalam melakukan penyuluhan komoditi pangan dengan baik, akan tetapi masih belum optimal disebabkan oleh keterbatasan sarana dan prasarana, akomodasi dan pembiayaan, serta kekurangan sumberdaya dan tenaga penyuluh. Selain itu, peran penyuluh baru mencapai aspek penyediaan saprodi, budidaya, dan panen. Penyuluh belum sepenuhnya membantu petani mandiri dalam hal pemasaran.

\section{Saran}

Berdasarkan kesimpulan di atas, penulis menyarankan untuk meningkatkan peran BPP sehingga dapat menjalankan fungsinya dengan baik dalam melakukan penyuluhan komoditi pangan. Peningkatan peran BPP tersebut dapat dilakukan dengan memberikan anggaran, sarana, dan prasarana yang memadai untuk kelancaran fungsi BPP. 


\section{DAFTAR PUSTAKA}

[Balitbangtan] Balai Penelitian dan Pengembangan Pertanian. 2015. Panduan Teknologi Budidaya Padi Salibu. Jakarta: Kementerian Pertanian.

[Dirjen Tanaman Pangan] Direktorat Jenderal Tanaman Pangan. 2017. Pedoman Pelaksanaan Kegiatan Padi 2017. Jakarta: Kementerian Pertanian.

Jamil MH, Jahi A, Gani DS. 2012. Kinerja Balai Penyuluhan Pertanian (BPP) dan

Dampaknya pada Perilaku Petani Padi di Sulawesi Selatan). Jurnal Penyuluhan. 8(2): 132-140.

Kresno S, Ella Nurlaela H, Endah Wuryaningsih, IwanAriawan. 1999. Aplikasi

Penelitian Kualitatif dalam Pencegahan dan Pemberantasan Penyakit Menular, Fakultas Kesehatan Masyarakat Universitas Indonesia bekerja sama dengan Direktorat Jenderal Pemberantasan Penyakit Menular dan Penyehatan Lingkungan Pemukiman Depkes RI. Jakarta.

Lesmana D. 2007. Kinerja Balai Penyuluhan Pertanian Kota Samarinda. EPP. 4(2): 24-31.

Marliati, Sumardjo, Asngari PS, Tjitropranoto P, Saefuddin A. 2008. FaktorFaktor Penentu Peningkatan Kinerja Penyuluh Pertanian Dalam Memberdayakan Petani (Kasus di Kabupaten Kampar Provinsi Riau). Jurnal Penyuluhan. 4(2): 92-99.

Pelawi WDP, Rosnita, Yulida R. 2016. Analisis Kelembagaan Penyuluhan Pertanian Di Kabupaten Kampar. Jurnal Ilmiah Pertanian 13(1): 1-13.

[Permentan] Peraturan Menteri Pertanian No. 61 Tahun 2008. 2008. Pedoman

Pembinaan Penyuluh Pertanian Swadaya dan Penuyuh Pertanian Swasta.

Sadono D. 2008. Pemberdayaan petani: paradigma baru penyuluhan pertanian di Indonesia. Jurnal Penyuluhan. 4(1):65-74.

Setiawan IG. 2005. Masalah-masalah penyuluhan pertanian. Jurnal Penyuluhan. 1(1):57-61.

[Simluhtan] Sistem Informasi Manajemen Penyuluhan Pertanian. 2018. [Internet]. Diakses pada 21 November 2018. [https://app2.pertanian.go.id/simluh2014/gst/welcome.php].

Sukiyono, K. 2018. Penelitian Survai dan Teknik Sampling, BPFP. Universitas Bengkulu.

Syabrina E, Hakim DB, Tonny F. 2009. Analisis Kelembagaan Penyuluhan Pertanian di Provinsi Riau. Jurnal Manajemen Pembangunan Daerah. 5(1): 32-46.

Syahyuti. 2016. Modernisasi Penyuluhan Pertanian di Indonesia: Dukungan Undang-Undang Nomor 23 Tahun 2014 terhadap Eksistensi 
Kelembagaan Penyuluhan Pertanian di Daerah. Analisis Kebijakan Pertanian. 14 (2): 83-96.

Undang-Undang Republik Indonesia No. 16 Tahun 2006. 2006. Sistem Penyuluhan Pertanian, Perikanan, dan Kehutanan. Jakarta. BadanPengembangan SDM Pertanian Departemen Pertanian. 